\title{
Precarious Suburbanization: Perceptions of Infrastructure Supply and Living Conditions in Suburban fraccionamientos of Guadalajara, Mexico
}

\author{
Alexandra Budke ${ }^{1}$, Hans-Joachim Bürkner ${ }^{*}, 2$ and Salvador Peniche Camps ${ }^{3}$ \\ ${ }^{1}$ University of Cologne, Seminar für Geographie und ihre Didaktik, Gronewaldstr. 2, 50931 Cologne, Germany \\ ${ }^{2}$ University of Potsdam, Institute of Geography, Karl-Liebknecht-Straße 24/25, 14476 Potsdam, Germany \\ ${ }^{3}$ University of Guadalajara, Department of Economy, Periférico Nte. 799, esq. Parres Arias, 45100 Guadalajara, \\ Mexico
}

\begin{abstract}
Over the past 20 years the model of suburban gated communities has become increasingly popular throughout the metropolitan regions of Latin America. Initially a socially exclusive phenomenon, usually confined to upper class clientele, gated settlements have now reached the middle classes. The production and marketing of such settlements sometimes even addresses aspiring lower class households. The case of recently established fraccionamientos in the metropolitan region of Guadalajara (Mexico) is indicative of this trend. It has created new problems of infrastructural supply which would not have been attributed to "gated" living before. Based on a comparative study of suburban settlements of varying socio-economic status, this paper seeks to contrast recent problems of infrastructural supply with basic modes of problem perception and everyday coping strategies developed by local residents.
\end{abstract}

Keywords: Coping strategies, fraccionamientos, gated communities, infrastructure, Mexico, perception, suburbanization, water.

\section{INTRODUCTION}

From 2000 onwards, there has been a surge in the popularity of the "gated" suburban housing model amongst Mexico's urban middle class. Suburban housing has recently been promoted much by the Mexican state. Referring to the constitutional right of every citizen to have access to land property, the state provides financial assistance to individual households to become house owners. As a consequence, metropolitan regions such as Guadalajara have seen an extensive expansion of suburban settlements, fostered by targeted state funding of medium to low budget settlement construction [1, 2]. Massively promoted by the Mexican government and local politicians, the lower middle classes, and even lower classes, found access to state funds and credit loans. This development has contributed to a rapid suburban sprawl. In the case of Guadalajara, suburban growth substantially accelerated in spite of modest or even stagnating population growth in the area as a whole [3]. The state subsidies coincided with a period of increasing social mobility at the beginning of the millennium, as well as intensified external and local investment in private housing, and the growing popularity of the globalized "single family home" model of good living. In the Guadalajara region, the particular combination of state incentives and new marketdriven housing demand has given rise to a booming construction sector specialized in the rapid development of suburban settlements. Within short periods, private devel-

*Address correspondence to this author at the University of Potsdam, Institute of Geography, Karl-Liebknecht-Straße 24/25, 14476 Potsdam, Germany; Tel: +49 331977 2285; Fax +49 331977 2717;

E-mail: buerkner@uni-potsdam.de opers have offered standardized settlement plans and established a multitude of settlements serving the diversifying demands of the increasingly segmented middle classes [3]. "Mega-housing development projects constitute a highprofit business for highly capitalized, large deve-lopers" [4]. Cheap land for large-scale projects can be found especially in remote suburban areas where conflicting interests and ecological problems create new arenas of controversy.

The initial preference of customers for gated communities gradually developed into a proliferation of different settlement forms. The 'classic' upper middle and upper class gated community was easily discernible in its circling fences, walls and gates guarded by security services. The housing structure consisted of villas or detached single family homes, surrounded by gardens and car parks [5]. While this model is still much in demand in Mexican cities (cf. [6]), the lower middle and lower classes have been accommodated in less luxurious environments [7]. Today around two thirds of all zoned suburban communities in Mexico are inhabited by members of the middle and lower classes [8]. The settlements often consist of large arrays of terraced houses, the green areas surrounding the houses often reduced to small strips, and the space in between houses gradually diminishing [9]. Security services are frequently not employed, mainly for financial reasons, and even surrounding fences or walls are sometimes absent. While they are generally accessible to visitors, they are still separated from other settlements or surrounding pasture by the closed, compact plot which signals exclusiveness. In Mexico this type of settlement has been named fraccionamiento in order to indicate the small subdivided space each house occupies, together with the uniformity of 
its outer appearance [10-12]. Of course, in some cases fraccionamientos also consist of gated estates, but in general they have "soft" gates and allow for relatively unrestricted access.

Contrary to former expectations raised by research on wealthy gated communities, living conditions turned out to be modest. Everyday living is especially difficult to manage for households of limited financial capacities. Since these places represent serious and overlapping dilemmas of urban development, they have become the source of increasing contestation and political controversy. Meanwhile they represent a labile urban development trend which we call "precarious suburbanization".

While a series of well-known, almost ubiquitous problems emerged from standard routines (e.g. land use conflict in ecologically sensitive suburban zones, marked segregation between and inside settlements, antagonistic suburban life styles), there are a number of lesser known problems connected to these precarious modes of suburbanization. Housing construction of modest pretensions entails architectural shortcomings, deficient infrastructure provision, the deterioration of water resources and the exposure of residents to contaminated soil and water [13]. In face of the ongoing global economic crisis, low-budget housing is part of a wider context of risky household strategies, failing social consolidation and rising political instability. Precariousness is also revealed by many failing individual projects of house construction, and by increasing remigration of disillusioned households to the core cities. These problems still await detailed empirical exploration.

A closer inspection of the current research landscape reveals that urban studies in Latin America nurture a serious research gap. While the suburban gated community, as a conspicuous upper class phenomenon, has frequently been investigated $[14,15]$, the less apparent problems generated by limited material resources, insufficient infrastructural supply and residents' attempts of coping with everyday shortcomings have received only minor attention.

Taking the metropolitan region of Guadalajara in Central Mexico as an example, this article identifies infrastructural mismatches connected to the establishment of segregated suburban settlements (fraccionamientos), and relates them to residents' perceptions of the living conditions in their settlements. These perceptions are conceptualized as part of a specific way of adapting to the constraints of suburban living. The main questions to be answered here are:

1. How do suburban residents living in fraccionamientos and gated communities perceive the infrastructural problems they face every day? Do these perceptions differ according to the socio-economic status of the individual household?

2. What ideas, orientations and practices do residents develop so as to cope with these problems? Do these orientations also display major differences according to the socio-economic status of residents?

Our empirical analysis is based on a questionnaire survey of suburban settlements which differ according to their socio-economic status (upper, middle and lower middle classes) and their specific location within the metropolitan area of Guadalajara. Given the growing social polarization of Mexico's urban society [5, 14], the analytical focus is on status-related differences of perceiving and coping. The basic assumption is that social disparities trigger specific ways of coping. This assumption is positioned against the widely-held conviction that traditional lifestyles are abandoned in favour of globalized lifestyles and cultural orientations, and that these are decisive to individual preferences for suburban life and "gated" living [8, 16]. Contrary to recent strands in the literature on urban development that tend to marginalize the category of social status in the analysis of gated communities and suburban lifestyles, we contend that status still, and increasingly, matters.

\section{EMPIRICAL MATERIALS AND METHODOLOGY}

\subsection{Sampling of Neighbourhoods, Questionnaire Design and Analytical Procedures}

Life in suburban gated communities implies a variety of context-specific individual and collective interpretations of living conditions. Knowing that the task of fully accounting for this variety would require the time-consuming implementation of qualitative methods [19], we nevertheless decided to apply a quantitative questionnaire survey. Otherwise the objective of attaining an overview over the suburban scene and the multifold socio-spatial situations included would have hardly been realized. Our decision was supported by the fact that up to date in Mexico there has hardly been any attempt to systematically record emerging patterns of suburban segregation, problems of infrastructure supply and residents' coping strategies. This research gap could only be approached by an analytical procedure which allowed for easy generalization of empirical findings.

The standardized questionnaire gave us the opportunity to meet several important requirements simultaneously. Firstly, we were able to develop a class-sensitive comparative approach which paid attention to the socio-economic varieties of suburban settlements. Structural information about the neighbourhoods, as well as opinions given by respondents, could be interpreted against different backgrounds of social class and factual infrastructural differences. Secondly, possible sources of misinterpretation given within an intercultural setting of data collection could be minimized in the questionnaire by using a simple, easy-tounderstand language, and by introducing a question-response scheme which could easily be managed even by poorly educated interviewees. As we found out during a pre-test in a selected lower middle class area, many residents were completely unfamiliar with being asked questions about their house and neighbourhood. They found it less challenging to tick a standardized answer than to give an individually verbalized opinion. Thirdly, the occasion of achieving a larger (socio-spatial meso- to macro-level) picture compensated for the escaped chance of doing in-depth inquiries into lifestyles, narratives and cultural codes. Of course, we considered the specific gaps of evidence produced by a quantitative instrument, especially with regard to lacking everyday accounts of social life. However in face of the objective of acquiring comparable, generalizable information about perception patterns, definitions of 
problems and basic coping strategies, these considerations were of secondary nature.

In the spring of 2012 we conveyed a survey of 342 households in selected suburban settlements (gated communities and fraccionamientos) of the Guadalajara metropolitan area. Sampling was focused on the top-growth zones of suburbanization in the northeast, and the southeast of the city region of Guadalajara. Given two pre-selected upper class and middle class areas, plus two lower middle class to lower class zones, interviewers consecutively walked every street in these neighbourhoods at daytime and presented their questionnaires to every third household. The standardized questionnaires had been developed in collaboration with Mexican scholars of the University of Guadalajara and ITESO. Pre-tests and main-phase interviews were done in mixed Mexican-German groups of students of the universities of Guadalajara, Potsdam and Cologne. A small number of collateral qualitative interviews with local experts in the field of suburban development helped to elucidate the structural framework of settlement expansion and to interpret the quantitative data.

The sampling of neighbourhoods aimed at covering the variety of residents' problem definitions. Variety was supposed to be triggered mainly by different structural settings. Therefore, two structural criteria guided the selection. Firstly, the sample took account for a sufficient scope of built forms - from open fraccionamientos to "real" (i.e. fenced and guarded) gated communities. Secondly, the settlements selected were required to map the socioeconomic spectrum of suburban residents. A basic distinction was made between upper, middle and lower middle rsp. lower class settlements. At first sight this differentiation appears to be rather schematic, yet it is plausible in theoretical, as well as in empirical, respect. It refers to the sharp socio-economic divide between societal macro-groups deepened by growing social polarization, as provided by the context of Mexico's economic growth in the first years of the millennium, as well as after the 2007 economic crisis [11]. Aggravating socio-spatial disparities in the Mexican context usually establish large differences in financial solvency and representations of social habitus, which in turn serve as core drivers of segregation. Both categories (social status and habitus) imply demarcations of social distance which often resemble traditional class boundaries. Closer inspection reveals that they are also related to recent differentiations in class-specific lifestyles. They are reinforced by symbols of spatial delimitation (uniform types of houses, high density of building, fences, walls, gates, armed security guards). In a Mexican context, the general trend towards ostentatious visualization and symbolic representation of social status $[9,17]$ seems to legitimize the increasing harshness of boundary-drawing.

While lifestyles, as a means of establishing classimmanent social distinctions, have become increasingly important in Mexican middle class milieus, they are not arbitrarily selectable, at least not in the way they are in more egalitarian societies (e.g. in West European industrial countries; see $[12,18])$. They contribute to the social construction of class-specific demarcations, instead of creating original criteria of social differentiation beyond class boundaries. Lifestyles (including the adoption of "adequate" housing styles and new modes of voluntary segregation) thus become instrumentalized for the purpose of hedging vertical differentiations between and inside individual classes in an exclusionary way. They hardly contribute to the horizontal differentiation of the domestic urban society.

In the metropolitan area of Guadalajara, which is the focus of this study, the zoning pattern of suburban settlement construction follows a pre-established pattern of social segregation. During the past ten years, suburban expansion has accelerated in spite of the modest population growth rates in the metropolitan region as a whole $[3,9,19]$. It has been most intense on the north-western and southern fringes of the city (see Fig. 1). Following a general west-east gradient of social status, the suburban settlements in the northwest and west consist of well-established, relatively prosperous upper middle class areas (e.g. in the municipality of Zapopan), whereas the southwest and southeast are characterized by lower middle class areas (e.g. Tlajomulco de Zuñiga) (cf. Fig. $\mathbf{2}^{1}$ ). However, there is a mosaic of status and settlement types, rather than a consistent zoning. As a rule, wealthier settlements in the west tend to follow a classical "gated" concept, whereas middle class settlements in the northeast (the municipality of Tonalá) or lower middle class areas in the south are of the more open fraccionamiento type (cf. [3]). The lower the social class, the more frequently terraced housing is contained in the settlements, and the smaller are the individual houses or flats [19]. Moreover, the lower the socioeconomic status of a settlement, the more peripheral is its location.

The survey was conducted in seven neighbourhoods located at the urban fringe and in the suburban zone of Guadalajara, representing the settlement types described above. The final sample comprised 342 questionnaires distributed among the neighbourhoods as follows: "Villas de la Hacienda" and "Hacienda Los Fresnos I and II" (125 interviewees), "Residencial Parques de Tesistan" and "Parques del Centinela" (131 interviewees), "Jardín Real" (84 interviewees). Respondents were handed over or read out a questionnaire containing 70 questions. Statistical analysis of the survey data was done using standard PC statistics software (GrafStat). Since most questions were multiresponse questions which did not allow for sophisticated statistical analysis, we confined ourselves to extracting absolute frequencies and table row/column percentages. For most questions, response categories were differentiated according to class differences.

\subsection{Basic Social Characteristics of the Sample}

In the questionnaire we implemented the indicators "monthly household income", "level of primary education", "car ownership" and "number of living rooms" to isolate homogeneous neighbourhoods and similar sets of living conditions. The vertical differentiation of the questionnaire sample was clear-cut, allowing for the identification of socio-economic sections that were hardly ever cross-cut by individual aberrations. In a similar fashion, the pre-

\footnotetext{
${ }^{1}$ The socio-economic status of the areas displayed by Fig. (2) is based on an aggregate index of 9 variables representing socio-economic features of the population. Computation refers to Argüelles and Garcia (2013) [33].
} 


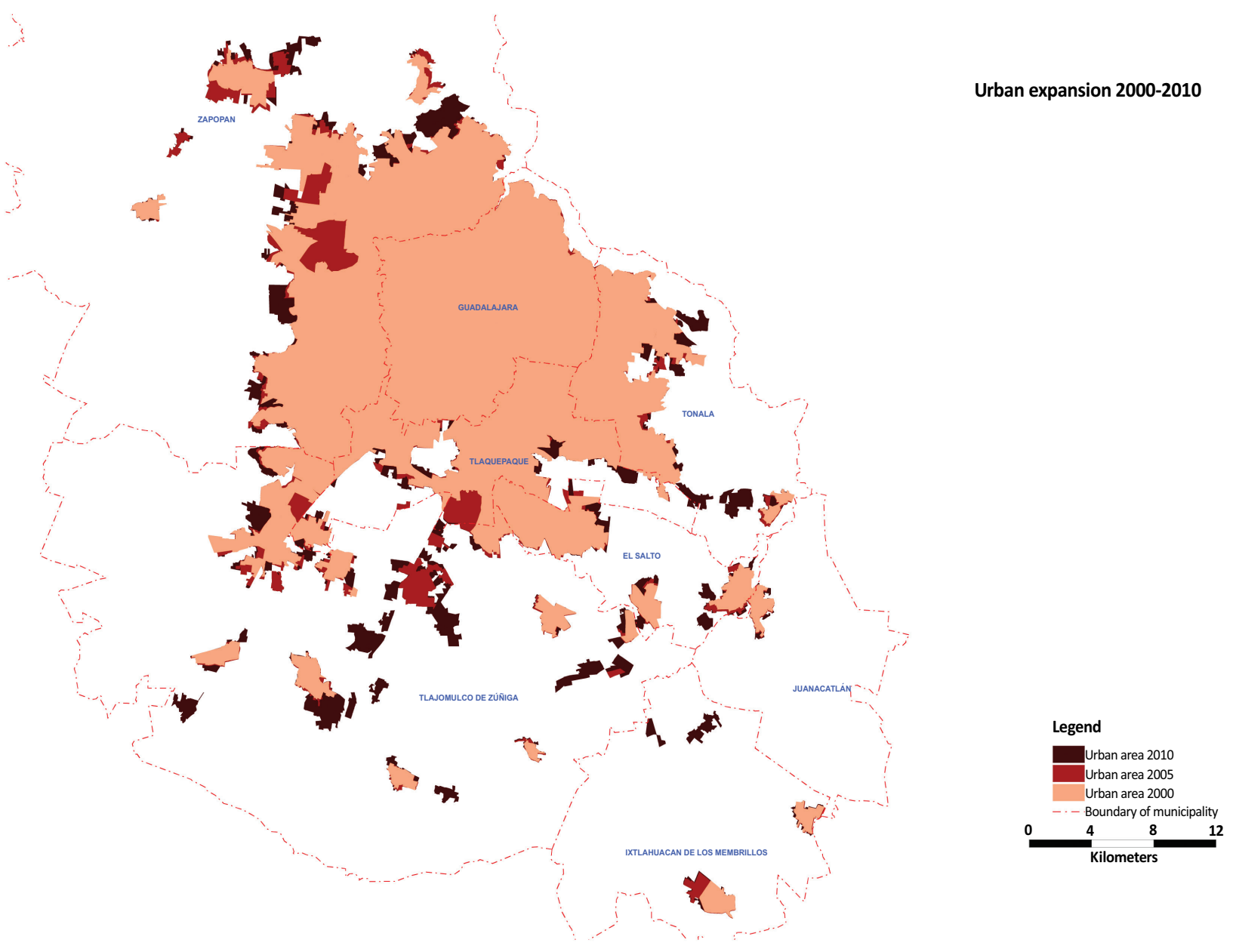

Fig. (1). Urban expansion of Guadalajara between 2000 and 2010 (Source: [20]; draft: S. Peniche Camps).

established class differentiation was reflected by the individual settlements.

Gender and age distribution of the sample displayed context-specific skewnesses. 193 out of the 342 interviewees were women. 129 men; 20 respondents did not indicate their gender (see Table 1). This means that the ratio of women amounts to $57 \%$. The slight overrepresentation of women is due to the circumstance that for reasons of security interviews could only be carried out during daytime. According to the traditional familial division of labour persistent in the Mexican society many men work outside their neighbourhood while their partners stay at home. The sample was also relatively young, reflecting that recent suburbanization in the Zona Metropolitana de Guadalajara has been sustained mainly by young families [3, p. 35]. The age structure also incorporates a higher proportion of women in early stages of the family life cycle: $56.1 \%$ of the interviewees were $18-35$ years old; $29.3 \%$ were $36-50$ years old; $12.5 \%$ ranged between $51-65$ years; and only $2.1 \%$ were older than 65 years.

Class affiliation was determined by an index aggregated from the variables of household income, occupational status, educational status, number of cars in possession of the household and number of bedrooms per home. Since income, as the decisive factor of purchasing power and stakeholder status on the housing market, is not the only component of class, a considerable degree of variation is effected within the class groupings of the sample. Hence household income not only varies between the classes, but also within the same class (Fig. 4).

At first sight, overall differences make a dramatic impression. $11 \%$ of the households had less than 2,000 Pesos (117 €) per month at their disposal, while at the other extreme $19 \%$ could draw on a monthly income of more than 30,000 Pesos $(1,758 €)$. Astonishing as the share of the sample's low-income residents might appear, they still must be regarded as privileged when compared to minimum Mexican lower class income levels. The statutory minimum wage in 2012 amounted to approximately $67 €$ per month.

In the middle class section of the survey the distribution of income varies considerably. A major part of the households have a monthly income of more than 6,000 Pesos (appr. $356 €$ ) at their disposal, but there still is a large subgroup which suffers from untypically low income, often caused by temporary job losses in the course of the country's economic crisis. High income, in contrast, is more in line with general expectations concerning the congruence of social status and income. Monthly income of more than 30,000 Pesos (appr. 1,758€) was almost exclusively realized by upper class households. 


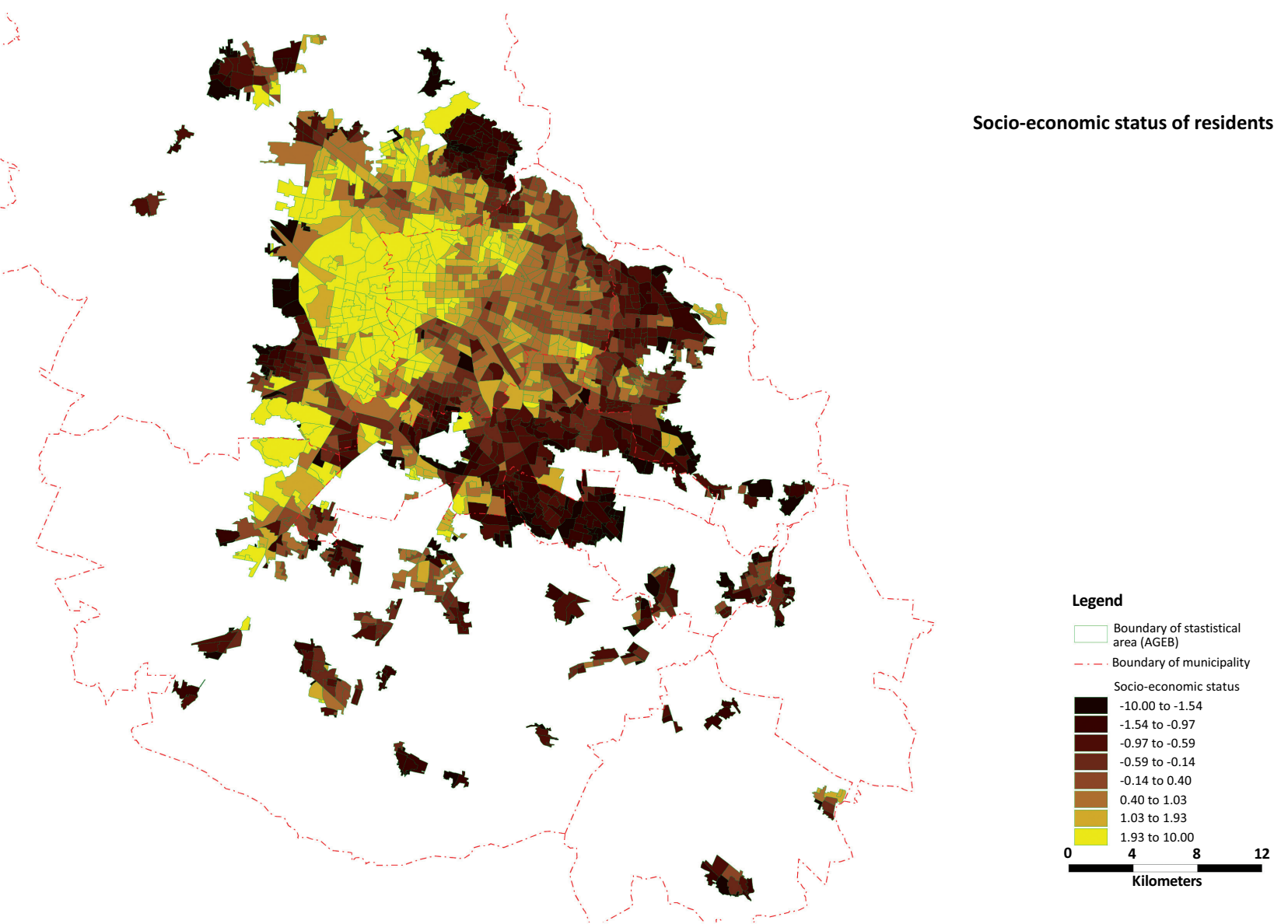

Fig. (2). Socio-economic status of neighbourhoods in the metropolitan area of Guadalajara 2010 (Source: [20]; draft: S. Peniche Camps).

Table 1. Basic social characteristics of respondents (Source: own survey).

\begin{tabular}{|c|c|c|c|c|c|c|c|c|}
\hline Years & Abs. & $\%$ & & Abs. & $\%$ & & Abs. & $\%$ \\
\hline $36-50$ & 100 & 29.2 & male & 129 & 37.9 & middle & 131 & 38.3 \\
\hline $51-65$ & 43 & 12.5 & no indication & 20 & 5.3 & upper & 84 & 24.6 \\
\hline Total & 342 & 100.0 & Total & 342 & 100.0 & Total & 342 & 100.0 \\
\hline
\end{tabular}

\subsection{Social Status and Segregation: Structural Characteristics of the fraccionamientos Under Analysis}

Usually the internal socio-economic structure of the fraccionamientos is fairly homogeneous (see similar findings by Chen [3]), allowing for a rough differentiation along class taxonomies. This housing type mirrors the high overall level of segregation in the metropolitan region of Guadalajara (cf. Fig. 2). Segregation is currently being reinforced by the activities of private housing developers. When establishing a fraccionamiento at a specific location they generally build houses that are identical in size, facilities and purchase price. The alleged desire of customers to live in a homogeneous neighbourhood is met by the calculated uniformity of the housing on offer [21]. Thus even varied demand becomes channelled towards a small number of architectural models offered. It ends up in 'pre-fabricated' forms of segregation.

\subsubsection{Lower Middle Class Neighbourhoods}

Located at the southern suburban fringe of the metropolitan region, some $20 \mathrm{~km}$ from the city centre, these neighbourhoods represent a typical combination of lowstandard housing and a population located at the lower end of the social scale involved in suburbanization (cf. [1]). The settlements "Villas de la Hacienda", "Hacienda Los Fresnos I" and "Hacienda Los Fresnos II", situated in close neighbourhood to each other (see Fig. 3), are circled by 


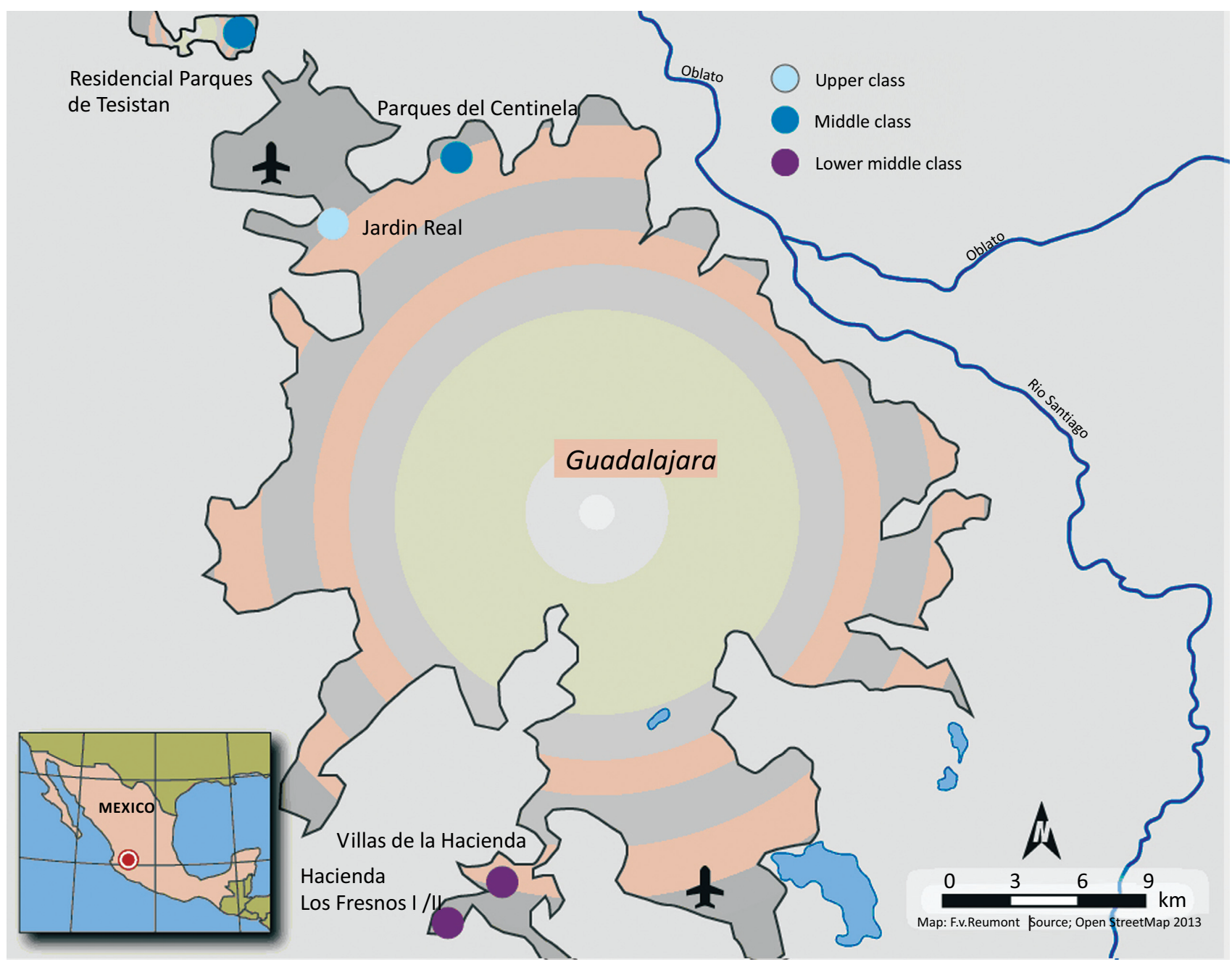

Fig. (3). Neighbourhoods studied (Draft: A. Budke).

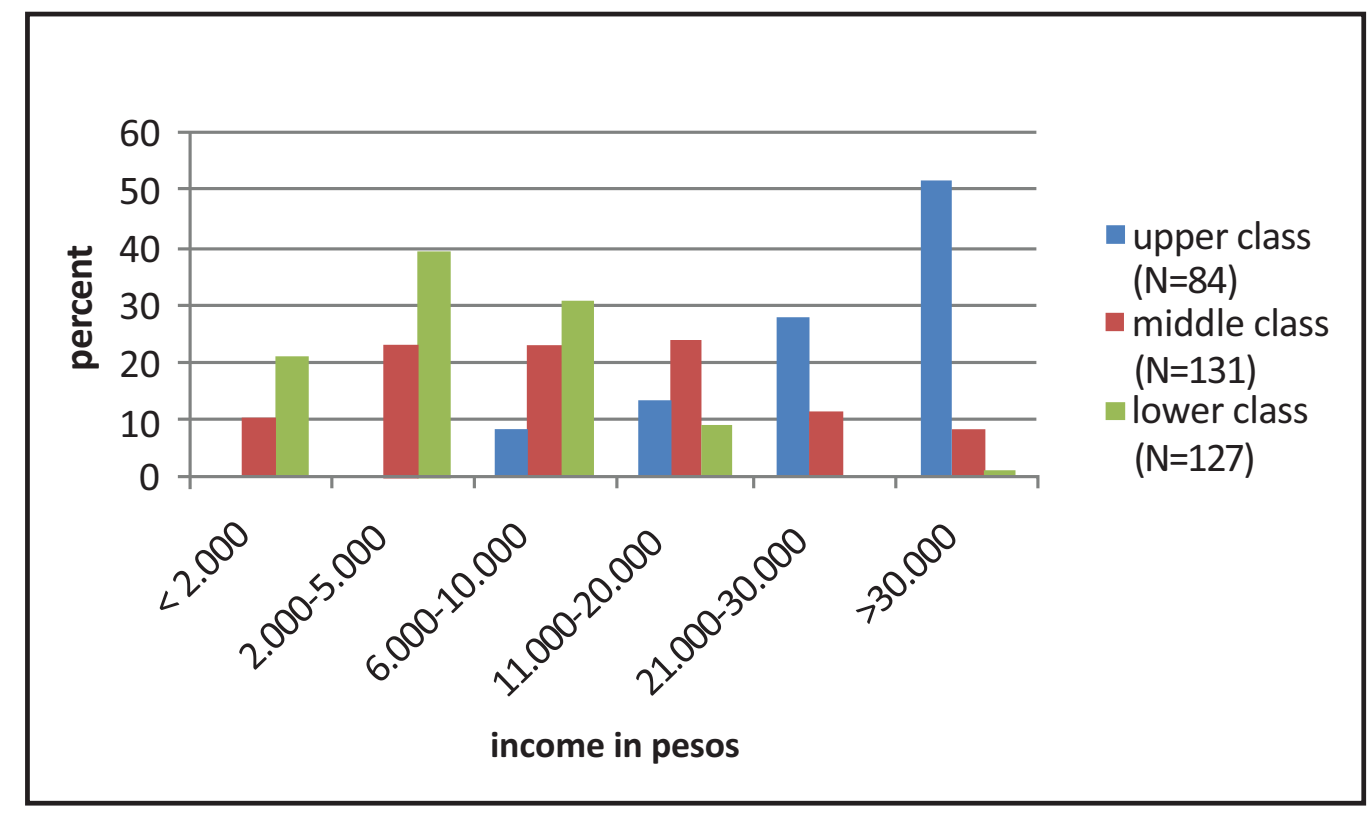

Fig. (4). Monthly household income in relation to class affiliation (Source: own survey; $N=342$ ). 
fences and closed by a gate. They consist of approximately 1,600 small single- or two-storey terraced houses of 40-60 $\mathrm{m}^{2}$ living area, equipped with modest facilities. The settlements have no shopping facilities (except from a small number of kiosks) or recreational space. Public transport is only reachable on a main road which runs in considerable distance from the settlements. Private mini-taxi cabs (i.e. motor bike rickshaws) serve as shuttles between the settlements and the next public bus stop on the main road (see Fig. 8).

Water supply is completely detached from public networks which do not reach this distant suburban area. Instead, water is gained by de-centralized ground water pumps inside the settlement, and by distribution through a local network of pipes. Waste water is disposed of in open sewers which run through the middle of the settlement, producing strong stench. In one of the settlements, the drainage of bathrooms and kitchens runs through pipes under a small front lawn, eventually leading to the gutter. Since the settlement was erected on small hills, waste water occasionally runs downhill through the streets into the open sewers.

We classified "Villas de la Hacienda" and "Hacienda Los Fresnos I and II" as lower middle class. Average household income is so low here that no major investment is possible, even if a family paid back the credit loans necessary for buying the house. We also found fewer car owners here than in the other districts. Furnishings and the size of houses in these districts are moderate, entailing a small number of bedrooms only. Furthermore the respondents' level of education was found to be lower than in the other districts.

\subsubsection{Middle Class Neighbourhoods}

The settlements "Parques del Centinela" and "Residencial Parques de Tesistan" in the northern suburban zone (see Fig. 3) are freely accessible. However, as a rule, individual houses are protected by fences and solid "microgates" at the plot boundary. Moreover, inside the settlement there are several dead-end streets designed as fenced and gated "zones within in a zone". The houses consist of twostorey terraced segments of $50-80 \mathrm{~m}^{2}$ size and standard facilities. Both settlements are connected to the public bus system, with bus lines running through the area. There are several grocery shops and a small sports area. Most parts of the settlements are connected to the public water supply system and enjoy public waste water management.

Following our indicators, the districts "Residencial Parques de Tesistan" and "Parques de Centinela" are inhabited by middle class house owners. A large number of the respondents in these districts had at least a school qualification comparable to the A-level and was consequently in a position to assume skilled employment. This, in turn, correlated with higher average income, bigger houses and a higher number of car owners than among those interviewees classified as "lower middle class".

\subsubsection{Upper Class Neighbourhoods}

The upper class settlement "Jardín Real" is separated from public space by fences, gates and private security guards, yet it cannot be regarded as a gated community in a strict sense because only cars are checked while pedestrians are given free access. Inside the settlement, however, there are several gated cul-de-sac areas which comply with the original definition. Large detached single family homes and luxurious villas prevail. In many cases the interviewers were greeted by domestic servants. Water provision is partly private and de-centralized (groundwater wells), and partly via connection to large public networks. The settlement is integrated into the public sewer system. The main street adjacent to the settlement provides numerous restaurants, cafés, bank offices and big supermarkets. In sum, the only district that can be classified unambiguously as an "upper class" neighbourhood is "Jardín Real". The interviewees from this district have a high level of education, well-paid jobs, live in big and luxuriously furnished houses and generally own one or several cars as status symbols.

In conclusion, the households vary considerably in terms of socio-economic position and occupational qualification, although they share the same form of settlement, i.e. the fraccionamiento.

\section{EMPIRICAL FINDINGS}

\subsection{Perception of Suburban Living Conditions}

The primary motivation to move to gated communities has often been described as a longing for security $[9,21]$. For our respondents this desire did not rank very high, compared to much stronger motives such as the status acquired from being part of a well-appreciated community, or the hope for achieving better living conditions for the family.

The survey data on individual perceptions of living conditions revealed one dominant negative item: the peripheral location of the neighbourhood. The majority of respondents named long travel distances to work as a vital problem (see Fig. 5). This rating reflects the fact that all settlements are located at a considerable distance from the core city. It also indicates that the suburban housing areas are not adequately served by public transport.

The estimations vary considerably according to the social status and the material facilities of the fraccionamientos. Lower class respondents mentioned long distances and public transport twice as frequently as the other groups. This social differentiation of problem cognition can be traced along other aspects of local living. With regard to "open waste water", "stench", and "health care" there is a hierarchical grading in the intensity of perception, descending from the high impact of negative aspects for lower middle class settlements to low impact levels for upper class neighbourhoods. This probably mirrors the actual exposure of the respondents to infrastructural deficiencies. For a larger number of issues, however, there is an asymmetric U-shaped proportion between the social classes, e.g. for the issues "water supply", "quality of tap water", "electricity supply", "garbage collection", "street quality" and "public transport". Negative rankings are given by both lower middle class (to a higher degree) and upper class respondents, albeit the latter do so to a lower degree. This can be interpreted as a cognitive and social divide: while lower middle class members evaluate their surroundings according to basic material deprivations they experience, upper class respondents express higher aspiration levels 


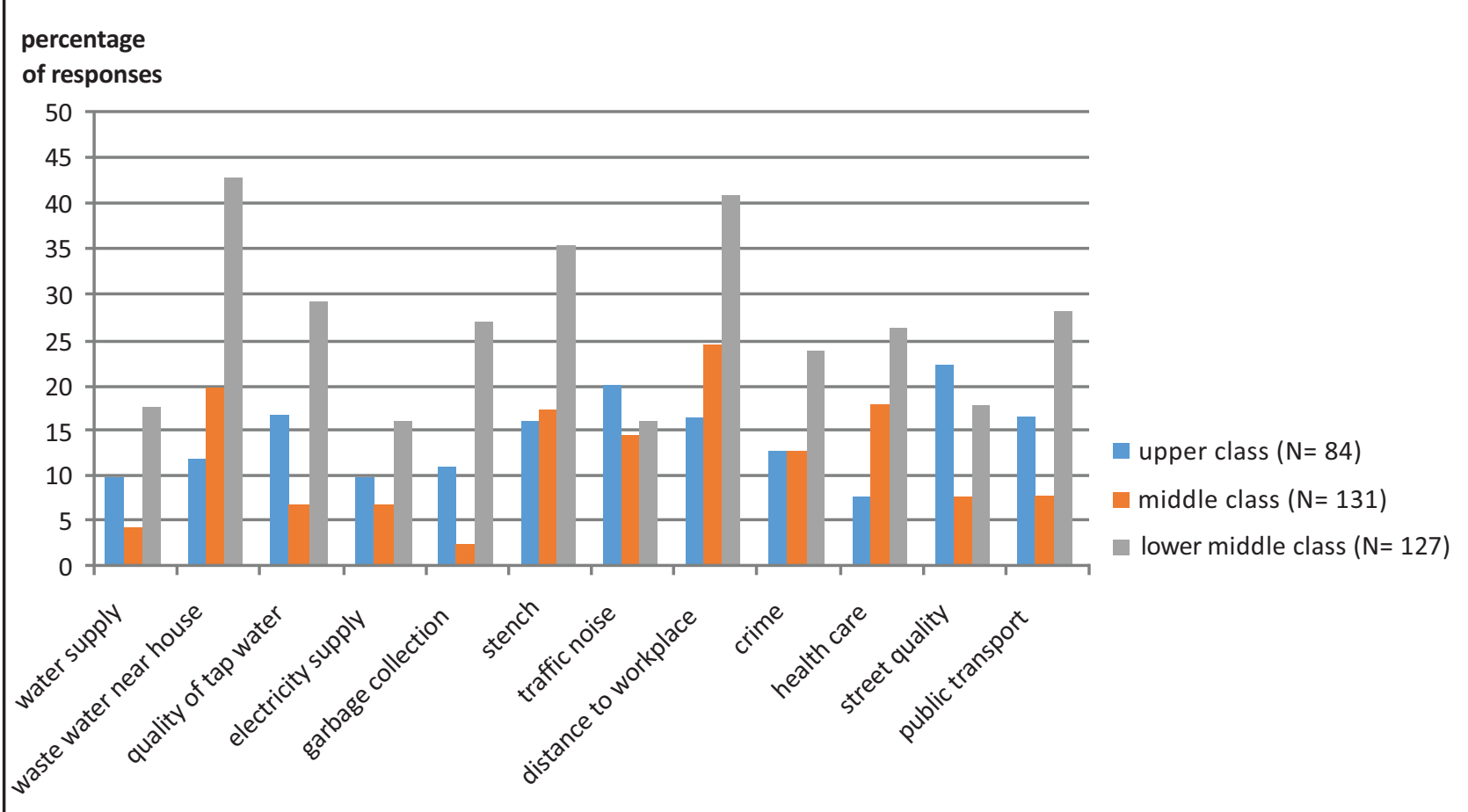

Fig. (5). Aspects of everyday life in the neighbourhood noted as problematic or very problematic (Source: own survey; $\mathrm{N}=342$ ). (Social status of the fraccionamientos of the sample: Lower middle class = "Villas de la Hacienda" and "Hacienda Los Fresnos I and II", Middle class $=$ "Residencial Parques de Tesistan" und "Parques del Centinela", Upper class = "Jardín Real").

which nevertheless cannot be served by the (relatively advanced) conditions of their community. Hence even luxurious housing standards occasionally give rise to complaints. Well-established middle class protagonists, in contrast, appear to have accommodated themselves to the conditions given - be it because of their reduced level of expectancy or because of the truly adequate infrastructure provision they found.

This empirical finding supports the assumption that in general the middle class achieved what they had been striving for, i.e. the best standard of living they could afford. For this class, the model of the fraccionamiento seems to have delivered what it promised. Nevertheless this "undramatic" image of middle class suburban life has to be put into perspective. Lack of basic infrastructure, which is obvious also in medium quality settlements, is not a triviality here. For example, none of the settlements under study had any health care facilities. In case of accident or disease hospitals or physicians outside the neighbourhood would have to be visited - which is not only a nuisance but also a concrete risk factor. Given such deficiencies, positive evaluations given by residents often indicate a high degree of normalization: many individuals feel that they have to get along with moderate or even poor conditions as long as there is no alternative.

A similar interpretation must be given to the observation that crime was not rated as a particularly important problem. Except for the lower middle class interviewees, who perceived it as highly significant, most respondents placed little emphasis on it. This finding is astonishing since,
- The traditional motivation for moving to a fraccionamiento or gated community had been the quest for security and the escape from crime [25];

- $\quad$ Expensive or advanced protective measures were not applied, such as fences, barbed wire, high-voltage wiring, walls, alarm systems, security guards, and so on. They were mainly present in more wealthy settlements, while many middle class neighbourhoods had just a few or even none of these;

- The local safety situation in Guadalajara was precarious at the time of the fieldwork; several attacks by drug gangs on public buses had been reported by newspapers only a couple of days before.

The obvious absence of a focus on criminality among upper class and well-established middle class individuals hints at a possible shift in the social and psychological function of the fraccionamiento. For most residents the desire to create a safe private microcosm ranked rather low. Instead they wished to find adequate representational forms for the social status they acquired, and for social distinctions based on lifestyles - which they often demonstrated by fashionable architecture and interiors they gave to their houses. For the lower middle classes, however, safety still was an important concern.

\subsection{Perception of Problems of Water Services}

In general, infrastructural problems in the suburban settlements of the fraccionamiento type increase with lower social status. Water supply has been a controversial issue in the Guadalajara region for decades. Working class residents 


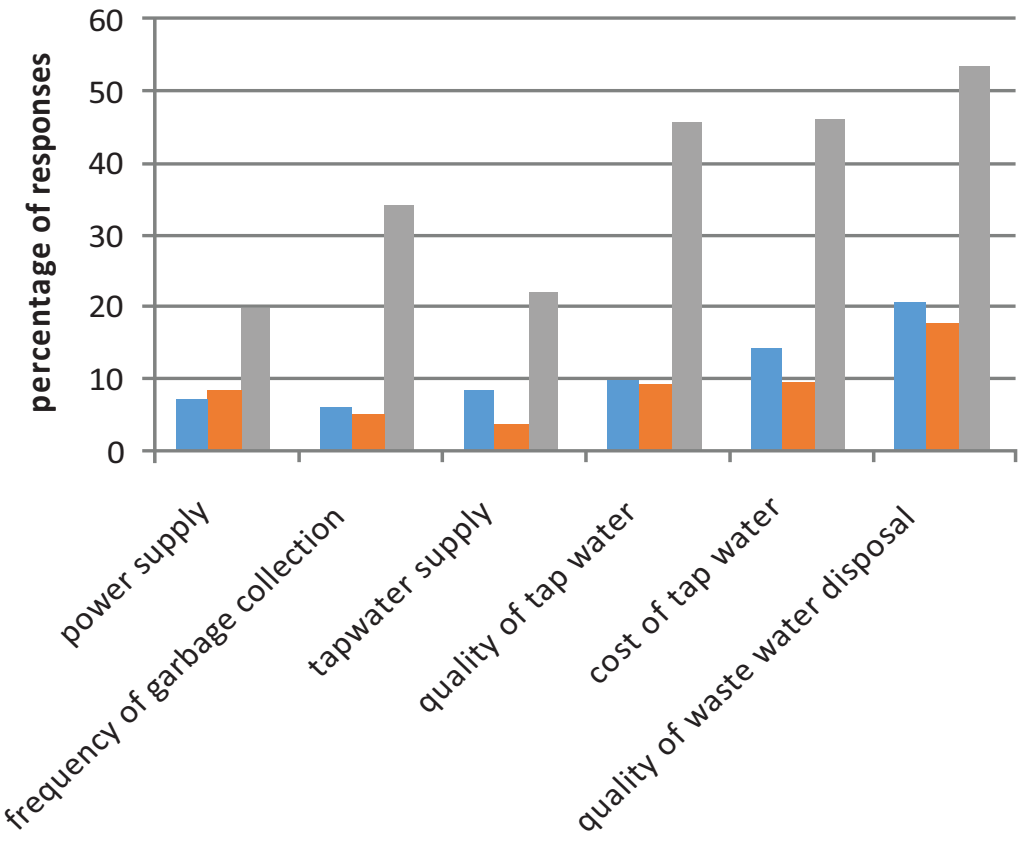

upper class $(\mathrm{N}=84)$

middle class $(\mathrm{N}=131)$

- lower middle class $(\mathrm{N}=127)$

Fig. (6). Aspects of infrastructural supply noted as problematic or very problematic by respondents (Source: own survey; $\mathrm{N}=342$ ). (Social status of the fraccionamientos of the sample: Lower middle class = "Villas de la Hacienda" and "Hacienda Los Fresnos I and II", Middle class = "Residencial Parques de Tesistan" and "Parques del Centinela", Upper class = "Jardín Real").

generally still are without sufficient access to clean water, and exposed to pollution and health problems [2, 13]. Since in literature and policy making these deficiencies have primarily been ascribed to marginal settlements, it is surprising to find them in an urban environment which officially ranks as well-developed. A closer look reveals that lacking infrastructure has often been caused by developers who did not take care of sustainable supply. In particular, low budget housing coincides with lacking access to public networks. This leaves lower class residents at a chronic disadvantage. It is not astonishing that this fact is reflected in our sample: here the availability of decent infrastructure obviously depends on individual financial resources. Lower middle class residents are relegated to settlements which in comparison are poorly constructed and badly equipped. The difficulties for low income households become particularly tangible in the field of water supply and sanitation.

With regard to water supply, the spectrum of relative disadvantage ranges from a low ratio of connectedness to the urban water network to aggravated exposedness to bad water quality and high costs of consumption. While $75 \%$ of all households were connected to the municipal water services network (the vast majority of them consisting of upper class and upper/average middle class households), 15\% (almost all of them lower middle class) received water from a local well. Households connected to public networks enjoyed a high standard of delivery (in terms of availability of tap water in the course of the day or relatively low levels of contamination), whereas households of lower status were exposed to intermittent supply, temporal water shortage and considerably worse water quality. Low-income respondents also mentioned the high cost of tap water as a big problem (see Fig. 6).

In a similar way, low-income households were especially burdened by inadequate methods of waste water disposal. $67 \%$ of all respondents declared that public space inside their settlements was polluted by waste water. Indeed the poorer fraccionamientos "Villa de la Hacienda" and "Hacienda Los Fresnos I/II" were traversed by open, odorous sewers. Interviewees reported that during the rainy season these sewers would regularly spill over and cause floods. Open sewers and especially flooding massively endanger residents' health by polluting home-grown and stored food; they also affect children and animals playing outside and can cause severe poisoning. Hence, they are much more than a mere aesthetic nuisance: they are an acute risk to health and well-being.

\subsection{Coping Strategies}

\subsubsection{Coping with Poor Water Infrastructure}

Most respondents were unsuspecting. They did not know much about the real conditions of water supply and sanitation in their settlement. Crucial for the capacity of those affected to take action is the question of how far waterrelated problems can be immediately recognized by the senses. 
As far as the quality of tap water is concerned, this is not surprising since only massive changes in the colour or smell of water can be sensed. However, this does not give a reliable indication of actual contamination. As a matter of caution, most households did not use tap water for drinking ( $92 \%$ of all respondents) or cooking $(72 \%)$. Status-dependent differences reveal that upper class settlements were regarded as less critical, as $43 \%$ of their households made use of tap water for cooking because of its (allegedly) better quality. In contrast, only $7 \%$ of lower middle class households used tap water, obviously because of its brown colour or bad smell. In order to cope with health risks, a large proportion of households, regardless of social status, regularly purchased purified bottled water. However, the overall high costs of buying bottled water are not equally manageable by households of different status. Prices have risen dramatically during the past years due to the commercialization and monopolization of the drinking water market by big transnational corporations (e.g. Coca Cola, Danone etc.). While upper class and upper middle class households easily cope with these costs, lower middle class households, especially those with many children, consider it an undue charge.

As far as sanitation and disposal of waste water are concerned, the individual cognition of related problems is not very far-reaching. For respondents living in lower middle class fraccionamientos, waste water seldom posed a problem, except if their house was situated directly at an open sewer. This proverbial "Out of sight, out of mind" attitude constitutes a coping mechanism in itself. One block's distance to a canal seemed to suffice to push the issue down the ranking list of problematic items. Upper and upper middle class households did not feel concerned either since waste water was not visible in their neighbourhood.

Particular knowledge about the ways waste water was diverted from their houses, where it went to and what happened to it after it had left the settlement, was generally poor or non-existent. Only $15 \%$ of all respondents stated that they knew that the water was not treated, instead carried directly into the next receiving water course (here the Río Santiago). In a similar way, detailed knowledge about the origins of water contamination was rare. Most respondents claimed it was "the industry" or "all inhabitants of Guadalajara" which caused the contamination of rivers and canals. However the complexity of causation and the dimensions of contamination were not a matter of clear perception or understanding. What was most troubling to learn from the empirical data was the fact that individuals of higher socio-economic status obviously did not make use of their potentially higher capacity to reflect upon the water problems they encountered.

\subsubsection{Coping with Adverse Suburban Living Conditions}

Most households tried to compensate for infrastructural shortcomings by exploiting private resources - in the family and within the neighbourhood. Especially for households of low financial capacities it was frequently necessary to demand help from the family or local friends. They preferred to find solutions by exploiting social resources in their environment (see Fig. 7). However, due to the complex

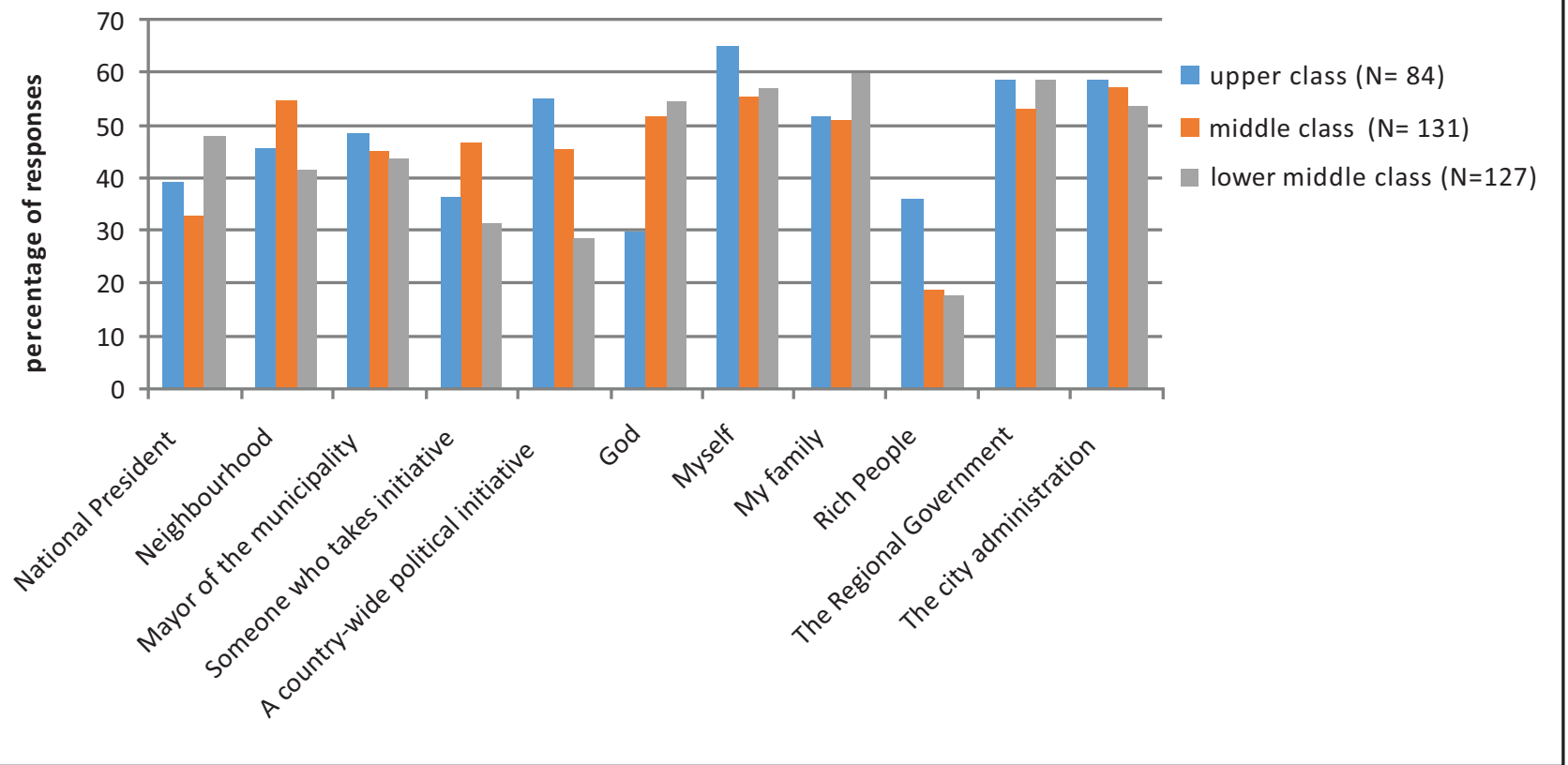

Fig. (7). Persons, institutions and organizations seen as having the capacity to solve problems (multiple responses) (Source: own survey; $\mathrm{N}=$ 342). (Social status of the fraccionamientos of the sample: Lower middle class = "Villas de la Hacienda" and "Hacienda Los Fresnos I and II", Middle class = "Residencial Parques de Tesistan" and "Parques del Centinela", Upper class = "Jardín Real”). 
nature of infrastructural problems these individual attempts of self-help often were limited. Lack of capital and technical comprehension usually prevented a wider institutionalization of routines and solutions.

A contrary approach, also favoured by a large number of households, consists in the delegation of responsibility to formal authorities and organizations. Respondents expect the city administration and the government of the Federal State of Jalisco to take the initiative and address infrastructural deficiencies. Upon request the majority of interviewees were not able to tell exactly how this should be done. Therefore the character of this opinion is rather vague and abstract.

An even greater degree of abstraction was displayed by respondents who favoured the higher instance of God to resolve their problems. Peculiar as it appears at first sight, this orientation is not simply a result of religious attitudes which might have included some inclination to develop fatalistic attitudes to the problems of everyday life. Since it is mainly the poorer households which reference this ultimate authority there is probably a sense of powerlessness among them, especially with regard to financial resources and political influence.

The answer "someone who takes initiative" refers to caring individuals and organized intermediary groups recently established in specific neighbourhoods. Particularly the asociaciónes de colonos (settlement associations), represent a collective attempt at providing self-help and selforganization. The activities of these associations comprise a number of local governance initiatives focusing mainly on the management of water infrastructure [4]. Although they take a lot of responsibility they usually are not organized on a long-term basis. Their rare attempts at exerting pressure on political decision-takers have seldom been successful.

\section{DISCUSSION}

The most controversial point about urban growth in Mexico is that infrastructure provision often does not keep pace with the prospection and completion of construction projects. Our are study region is no exception to this rule. Although overall growth rates in the Guadalajara metropolitan region have been moderate over recent years, the sectoral growth of the fraccionamiento type of development has actually accelerated [22]. Infrastructural deficiencies have grown particularly with the expansion of lower middle class settlements. A number of underserved or neglected areas developed south of the city, especially in connection with inexpensive house construction for the needs of lower middle class customers. Infrastructural problems mainly relate to public transport, water supply and sanitation.

In the outer peripheral zones, public transport is barely accessible to local residents due to bad connections to the traffic network. This has given rise to new motor bike (rickshaw) taxi services taking commuters from their home to the next bus stop (see Fig. 8). These services are usually provided on an informal basis.

Water supply is subdued to the rules of scarcity in a region generally lacking natural water resources, sufficient network coverage and adequate quality of standardized network supply. Access to clean water has become a major issue of political and social struggle, not only in Mexico as a whole [22] but in particular in the contested metropolitan region of Guadalajara [23-25]. The city of Guadalajara receives about $70 \%$ of its tap water from surface aquifers, mainly from the Lake Chapala nearby. In general the water of the lake is in bad condition. It arrives from feeders (e.g. the river Lerma) which are heavily contaminated by industrial and agricultural emissions. This water gets pumped to the city in a $60 \mathrm{~km}$ long pipeline and receives only rudimentary purification treatment [25]. Hence tap water in the city of Guadalajara is not drinkable. Moreover, sinking water levels due to voluntary extraction of water from the lake's intake, the Lerma River in central Mexico, have made reliable and regular supply a rarity. Due to poor water quality and unreliable supply by public water providers, many wealthier neighbourhoods left the communal water supply system and established high-class de-centralized systems. At the other extreme, lacking access to water resources has made poorer communities develop a low-standard form of de-centralized water supply, often informally organized by means of local wells, pumps, and by illegally collecting water from open sources [26, 27]. This dual pattern, which originally emerged in the metropolitan core area, has become re-established in the suburban zone of Guadalajara, albeit with one important difference. Core city neighbourhoods often develop de-centralized systems organized mainly by residents' initiatives. They establish technological recesses by compensating for lacking network supply in particular areas (for conceptual implications see [28]). In suburban settlements however it is the developer who takes care of the basic supply. In many cases, only a very rough settlement infrastructure has been built, e.g. by drilling a well and distributing ground water through a local pipe network which does not exceed the settlement boundaries. Since this initial structure has to be technically maintained, and since local water resources decline due to the growing overexploitation of groundwater, combined with rapidly sinking groundwater levels in the region, there are many settlements, especially in the southern suburban zone, which suffer from water shortage and dry taps several times a day [13].

Waste water sanitation is an even larger problem since in the suburban area there are no major underground sewerage networks and only very few sewage plants. The whole metropolitan zone has two large sewage plants which are capable of processing only a small portion of the total metropolitan waste water [13]. Therefore about $85 \%$ of all urban waste water goes untreated into the receiving water courses of the Río Atemajac and the Río Santiago [4]. One of two new sewage plants under construction at the time of our investigation was located in the southern suburban zone of Guadalajara. However already at the time of its construction it became clear that its capacity to serve the suburban zone would be insufficient, and that it would only be partially connected to the larger sewerage system. Hence standard sanitation facilities for fraccionamientos have been based on de-centralized solutions lacking modern sewage technology. Especially poorer settlements have only small pipe systems which collect waste water into open channels running through or around the settlements (for example, see Fig. 9). 


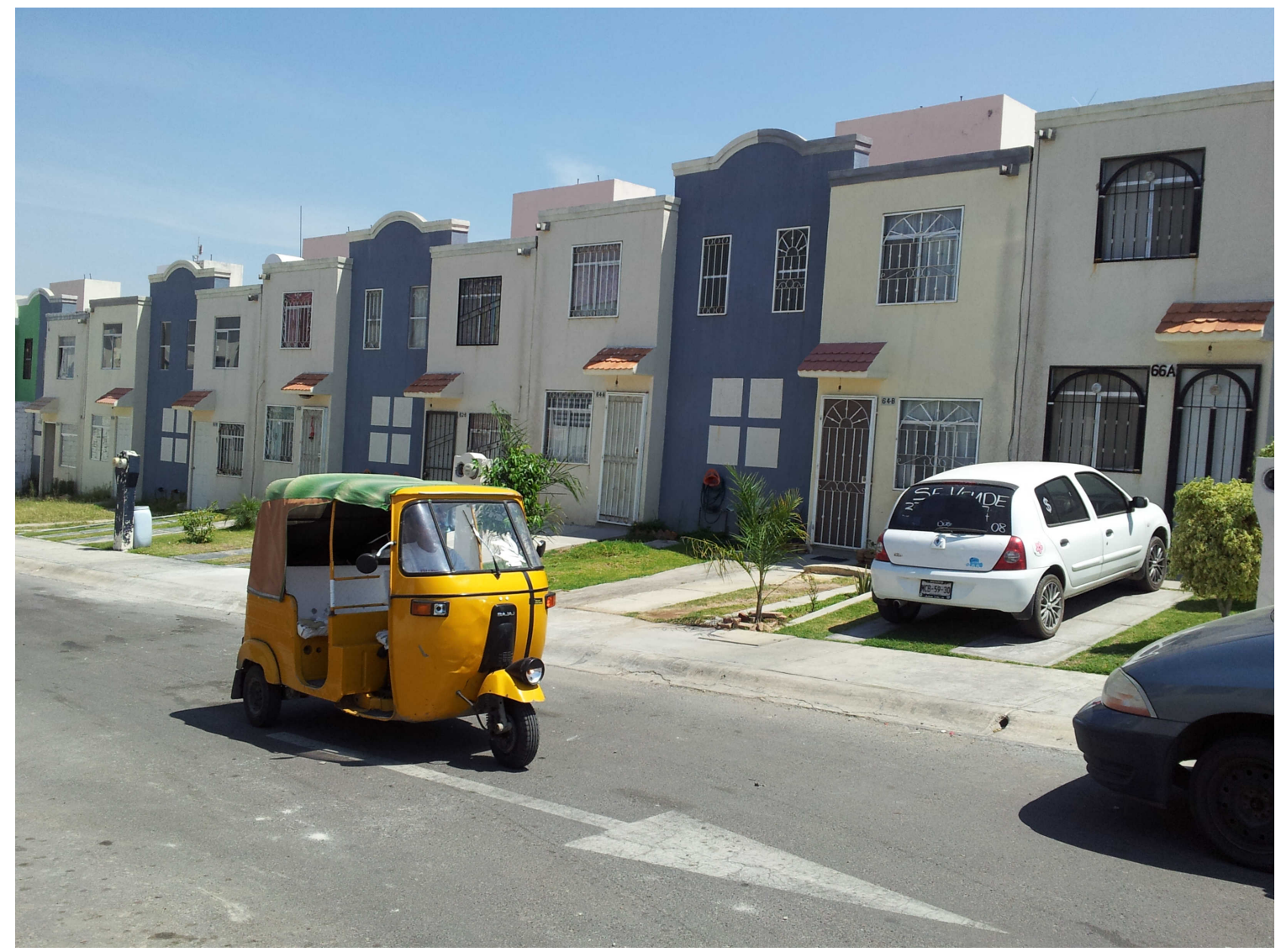

Fig. (8). Rickshaw taxi cab in suburban fraccionamiento compensating for the lack of public transport (Photograph: J. Bürkner).

Receiving water courses are regularly polluted by inflows of untreated water from open waste water channels. So the subsequent receiving water courses take up a poisonous charge which makes them useless for drinking water production. Since many fraccionamientos have been built without any coordinated planning in ecologically sensitive rural zones, or even in water protection areas, they contribute greatly to the degradation of the suburban environment.

The research presented here focuses on the individuals and groups coping with these structural conditions. In most cases, before moving into suburban gated communities or fraccionamientos, suburban house buyers or tenants knew little about the particular conditions they would find there. Infrastructural problems usually rise with the sinking social status of the settlement, hence lower middle class fraccionamientos are particularly charged. It is here that the problems and hardships of suburban living become obvious. These spatial units easily lend themselves to closer empirical investigation. The solution to infrastructural problems gathered here puts considerable strain on the lives of middle and lower class families, in addition to a number of other distressing living conditions stemming from status acquisition and financial shortages. In particular these households face the following economic problems:

They have to manage transport from their homes to varying destinations (1-2 workplaces, schools, recreation venues, shopping venues). Due to lacking public transport one or two cars are indispensable for maintaining everyday activities.
- They take up loans which in many cases drive them to the limits of what is endurable for low to middle income households. Loans have become a special risk factor in recent times of economic crisis because household members are in danger of getting unemployed or have already lost their jobs.

- Limited and/or sinking financial resources make households leave construction projects unfinished; often individual families continue to live in halfestablished homes for longer periods; in extreme cases they abandon their houses and return to affordable neighbourhoods in the city centre.

In some cases plans for moving to the new home in the suburban area had to be postponed or even cancelled.

In sum the disadvantages and deficiencies of suburban living might render future individual plans and ambitions even more precarious than they already have been. This is not only indicated by the rising number of returnees to lowcost inner-city neighbourhoods of Guadalajara, where they are forced to re-establish life at a reduced standard ${ }^{2}$; it is also illustrated by the unknown number of households living beyond their financial capacities - having spent their savings on the purchase of their suburban home and paying off debts -

\footnotetext{
${ }^{2}$ In the summer of 2013, national newspapers reported a nation-wide vacancy rate of $34 \%$ in state-supported suburban settlements established since 2012. The obvious decline in demand was attributed to the poor quality of construction, lacking infrastructure and problems of financing which deterred potential and actual inhabitants [34].
} 


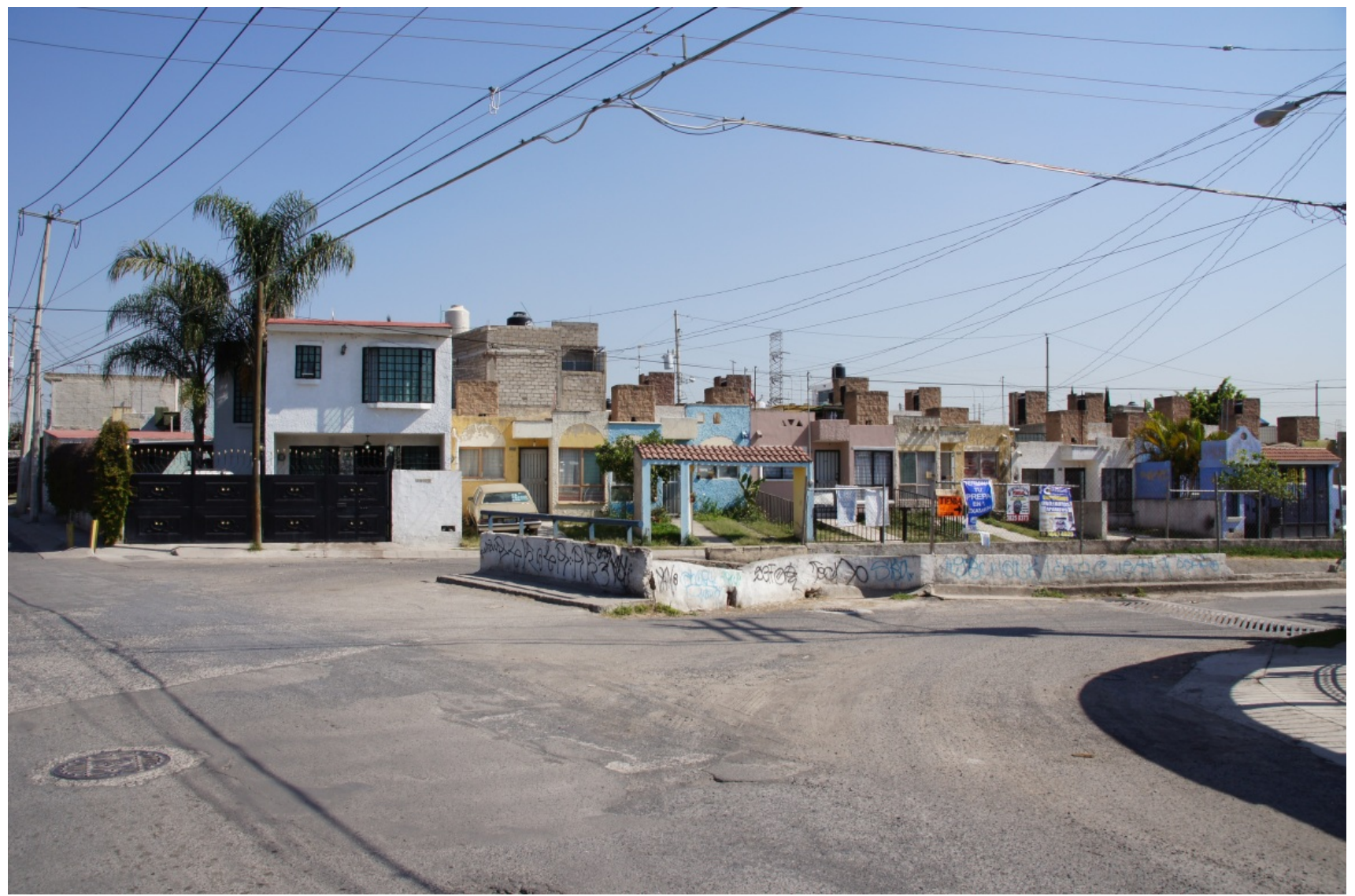

Fig. (9). Open sewer in a peripheral fraccionamiento south of Guadalajara (centre of the picture, small murals building the embankment) (Photograph: A. Budke).

and who are thus incapable of making another move to escape burdening living conditions.

Apart from the documentation of problem perceptions and coping strategies directly triggered by such local framing conditions, our empirical findings also address a number of analytical gaps in the literature on suburban development and gated communities in Latin America:

Firstly, they indicate that suburban living has proliferated into a variety of settlement forms which more and more deviate from the original model of the gated community. Most studies on gated communities envisage this model as being part of a general structural transformation of the Latin American city. It represents an increase of social disparities over the past 20 years, whereby large-scale segregation patterns are replaced by small-scale segregation and functional fragmentation [15, 24, 25, 29]. This spatial down-scaling has been attributed to the increasing social differentiation and polarization of social classes at a national level. While this roughly holds true for the Mexican case, it nevertheless does not cover the full range of causation. Another strong influence must be recognized which is exerted by global economic fluctuations. Financial global instability and subsequent national economic crises directly affect the economic situation and mental dispositions of large social groups.
Although it is a widely held belief that globalization is a fundamental contextual factor of the restructuring of local living conditions, urban studies have hardly ever taken into consideration the micro-social consequences of global change. At best they conceptualized them as abstract framing conditions of urban development. Even in case individual studies account for increasing multi-scalar references to globalism made by local stakeholders of "developing" or "emerging" regions [5, 15], there is hardly any attempt to incorporate such a perspective in studies on gated communities or fraccionamientos in Mexico. We make a point here for interpreting empirical findings on local restructuring, such as those described above, within a larger context of global economic imbalance. In this optic, global economic crises and the subsequent destabilizing of economically vulnerable domestic groups must be conceptualized in such a way that they lose their analytical abstractness. This can be achieved by assuming that the ups and downs of globally induced social mobility have direct implications to social practice and urban re-structuring: They trickle down to precarious, ipso facto structurally differentiated modes of suburbanization. This allows for a better explanation of the Mexican experience of suburbanization. In this perspective, the recent social decline of Mexican lower middle class households after the global financial crisis, and fears of further 
decline, inflate a peculiar local dynamic of urban restructuring. Whereas the housing policy by the Mexican state seeks to stabilize proliferating low- to middle-standard housing projects for social groups under increasing economic pressure, these groups hardly feel any relief. Individual attempts at establishing housing property in the suburban area have been failing in increasing numbers because of income shortage and fluctuation. Under such conditions, taking house loans is not a stabilizing factor of life conduct; in fact it is a risk which many households cannot afford to take any longer. Abandoned houses in many peripheral fraccionamientos not only indicate individual misfortune but also the impact of broader economic change and political mismanagement.

Secondly, our analysis allows us to contend that the neglect of material infrastructure in the course of suburban expansion substantially affects the social conditions and everyday restrictions faced by economically vulnerable participants of suburban expansion. Up to date, the social relevance of important parts of the suburban structure, namely technical infrastructure, has seldom been the focus of systematic analysis. Problem perceptions of the specificity we encountered indicate that suburban house buyers are systematically directed into pockets of infrastructural over- and undersupply, depending on their purchasing power. This polarized channelling of demand does not simply stand for the selfregulating workings of a particular suburban housing market; rather, it is an outcome of the contingent, sometimes chaotic spatial allocation of material artefacts according to the strategies of private developers. Hot spots of excellent $v s$ insufficient water infrastructure alternate in a fragmented suburban landscape. In this way, political and material struggles about access to, and usage of, water resources produce a specific spatial fix. At the same time, they become enacted by local agents within the urban setting they face. Members of the lower end of the power hierarchy involved are made to develop specific coping strategies which have not been noted much by policy makers and researchers. They continue to constitute white spots on the map of our knowledge about heterogeneous suburban settlement expansion [22].

Thirdly, coping strategies developed by local residents in suburban environments deserve wider analytical recognition. This research gap is astonishing since over the past 10 years living conditions inside gated communities have been examined by a growing number of studies. Especially for the historical home country of the Latin American gated communities movement, Chile, solid empirical findings have been achieved [30]. There is good evidence about the social points of departure, the individual motivation to move to gated settlements, the lifestyles involved, the reality of living in communities closed-off from their surroundings, the individual problems of bridging the 'inner' and 'outer' worlds of gated housing, the symbolism involved in socio-spatial exclusiveness, etc. [8, 31]. However, when it comes to the coping strategies that local residents develop in relation to long-distance commuting, inadequate infrastructure provision and lack of access to infrastructural facilities for relatively immobile members of the gated communities (e.g. young people), empirical evidence remains rather thin. Exceptions are provided by recent studies on "gated" suburban youth in Chile [32]. For the context of Mexican suburbanization, our own empirical findings (see the discussion above) may have contributed to filling the research gap a bit.

\section{CONCLUSION}

The thesis of precarious suburbanization has largely been supported by our survey data. The response to structural conditions given by local households in upper and middle class fraccionamientos displays a fundamental divide in infrastructural quality between upper class rsp. mainstream middle class, and lower middle class neighbourhoods. The prestigious model of the gated community which lent itself to recent low-budget imitations only partially applies to the poorer households involved. Although for many lower middle class households the mere capability to move into low-standard fraccionamientos means a rise in social status, this achievement does not guarantee a carefree life. It is often paid for dearly with a life of material instability, endangered by economic downturn, hardened by infrastructural deficiencies, and in some cases even by severe threats to health and well-being. The case of water infrastructure in poorer suburban settlements shows that households try to normalize and accommodate themselves to such a precarious situation as much as possible. Nevertheless, apart from shortterm tactics of managing risks and shortcomings, no sustainable coping strategies are in sight. Mutual help on a neighbourhood basis and even feeble attempts at establishing local self-organization rarely have lasting effects. Moreover, they seldom reach beyond the individual settlement. Local initiatives hardly ever impact upon the political sphere and decision-makers. Being left alone is not only a feeling but also a structural reality here. It is addressed by occasional down-to-earth self-help but it also results in a strong sense of futility.

Social inequality has become a decisive factor in various reactions to suburban living conditions. Those households which are better off in financial terms realize higher degrees of freedom when it comes to managing infrastructure and everyday life in the neighbourhood. They have more opportunities to realize their lifestyle-oriented ambitions. Those who are bound to endure poor infrastructural conditions tend to be trapped by the intricacies of their material status. Rising numbers of households failing to establish themselves in suburbia, being compelled to sell their house and to return to the inner city, indicate that the fraccionamiento has not been a sustainable model of living yet - at least not for everyone.

\section{CONFLICT OF INTEREST}

The authors confirm that this article content has no conflict of interest. 


\section{ACKNOWLEDGEMENTS}

Declared none.

\section{REFERENCES}

[1] Inclán-Valadez MC. The 'Casas GEO' movement: An ethnography of a new housing experience in Cuernavaca, Mexico. London: London School of Economics and Political Science 2013. Available from: http://etheses.lse.ac.uk/726/1/Inclan-Valadez et hnography_housing_Mexico_public.pdf

[2] Venegas $\mathrm{CH}$, Castañeda HP. El crecimiento urbano y las características socioeconómicas de la Zona Metropolitana de Guadalajara: la generación de áreas pauperizadas. (Urban growth and socio-economic features of the metropolitan zone of Guadalajara: the production of poor areas). Carta Econ Reg 2005; 17(94): 3-15.

[3] Chen Y. What Is Unique about Fraccionamientos? Study of a settlement type in two municipalities in Guadalajara Metropolitan Area. Texas: University of Texas-Austin 2012. Available at http://soa.utexas.edu/files/gis/Yu.pdf

[4] García OH. Gestión del agua en la periferia urbana: Tlajomulco de Zúñiga. (Water management in the irban periphery: Tlajomulco de Zúñiga). In: García OH, Bürkner HJ, Eds. Gobernanza y gestión del agua en el occidente de México: la metrópoli de Guadalajara. (Water governance and management in West Mexico: The metropolis of Guadalajara). Guadalajara: ITESO 2012; pp. 245-82.

[5] Aguilar A. Globalization regional development, and mega-city expansion in Latin America. Analyzing Mexico City's peri-urban hinterland. Cities 2003; 20(1): 3-21.

[6] Graizbord B, Rowland A, Guillermo AA. Mexico City as a peripheral global player: The two sides of the coin. In: Richardson HW, Bae CHC, Eds. Globalization and Urban Development. Berlin: Springer 2005; pp. 147-64.

[7] Peralta BG, Hofer A. Housing for the working class. On the periphery of Mexico city: A new version of gated communities. Social Justice 2006; 33(3): 129-41.

[8] Borsdorf A. Das Ende der Stadt in Lateinamerika? Tendenzen der Stadtentwicklung und Verstädterung. (The end of the city in Latin America? Trends of urban development and urbanization). Österr Gesch Lit Geog 2006; 50(4): 238-52.

[9] Sáinz ME. Urbanismo y arquitectura del miedo: reflexiones sobre los fraccionamientos residenciales cerrados en México. (Urbanism and architecture of fear: reflections on gated fraccionamientos in Mexico). CYTET 2002; 34: 133-4.

[10] Cabrales Barajas LF, Canosa Zamora E. Segregación residencial y fragmentación urbana: Los Fraccionamientos cerrados en Guadalajara. (Housing Segregation and Urban Fragmentation: The Gated Fraccionamientos in Guadalajara). Espiral 2001; 7(20): 22353 .

[11] Cortés F. Pobreza: desigualidad en la distribución del ingreso y crecimiento económico. 1992-2006. (Poverty: inequality of income distribution and economic growth. 1992-2006). In: Cortés F, de Oliveira O, Eds. Desigualidad social. (Social inequality). El Colegio de México: Mexico 2010; pp. 61-100.

[12] Keim KD. Milieu und Moderne: Zum Gebrauch und Gehalt eines nachtraditionalen sozial-räumlichen Milieubegriffs. (Milieu and Modernity: On the usage and content of a post-traditional notion of socio-spatial milieus). Berl J Soziol 1997; 7(3): 387-99.

[13] Miranda NB. Grandes desarrollos habitacionales en la Zona Conurbada de Guadalajara. (Big housing areas in the suburban zone of Guadalajra). Espiral 2007; 39: 111-37.

[14] Atkinson R, Blandy S, Eds. Gated Communities. New York: Routledge 2006

[15] Giglia A. Gated communities in Mexico City. Home Cultures 2007; 5(1): 65-84

[16] Coy M. Gated communities and urban fragmentation in Latin America: The Brazilian experience. GeoJournal 2006; 66(12): 12132 .

[17] Doose A. $47 \mathrm{~m} 2$ Legebatterien-Peripherie: Massensiedlungen für die unteren Mittelschichten von Mexiko Stadt. (47 sq m periphery of laying batteries: Mass settlements for the lower middle classes of Mexico City). In: Becker A, Burkert O, Doose A, Jachnow A, Poppitz M, Eds. Verhandlungssache Mexiko Stadt: Umkämpfte Räume. Stadtaneignungen, imaginarios urbanos. (Mexico City, a matter of negotiation: Contested spaces. Appropriation of the city, urban imaginaries). Berlin: b_books 2008; pp. 67-76.
Berking H. Lebensstile, Identitätspolitiken und Gestaltungsmacht. (Lifestyles, Identity politics and the Framing of Power). Gewerkschaft Monatsh 1996; (8): 488-93.

[19] Barajas CLF. Tendencias recentes de las urbanizaciones cerradas y polarización residencial en Guadalajara. (recent tendencies of development of gated communities and housing polarization in Guadalajara). Guadalajara: Universidad de Guadalajara 2006.

[20] INEGI (Institudo Nacionál de Estadística y Geografía) Ed. Censo de población y vivienda. (Population and housing census). Aguascalientes, Mexico: National Institute of Statistics and Geography 2000, 2005 and 2010.

[21] Kanitscheider S. Condominios und fraccionamientos cerrados in Mexico City - Sozialräumliche Segregation am Beispiel abgesperrter Wohnviertel. (Condominios and fraccionamientos cerrados in Mexico City: Gated communities as an example of socio-spatial segregation). Geogr Hel 2002; 57(4): 253-63.

[22] Castro JE. Water, power, and citizenship: Social struggle in the Basin of Mexico. London: Palgrave Macmillan 2006.

[23] Budke A, Bürkner HJ. Wasser und Stadtentwicklung in einem Schwellenland - Ausgangspunkte einer sozialgeographischen Exkursion. (Water and Urban Development in an Emerging Country: Points of Departure of a Social Geographical Excursion). In: Bürkner H, Budke A, Eds. Wasser, Gesellschaft und städtischer Raum in Mexiko: Auf den Spuren des lokalen Umgangs mit Problemen der Wasserversorgung und Abwasserentsorgung in der Metropolregion Guadalajara. (Water, Society and Urban Space in Mexico: Tracing Local Practice of Water Supply and Waste Water Disposal in the Metropolitan Region of Guadalajara). Potsdam: Universitätsverlag Potsdam 2009; pp. 13-36.

[24] Hernández-Valdés A. Agua y economía: Una propuesta hidrológica para Guadalajara. (Water and the economy: An hydrological plan for Guadalajara). Tlaquepaque: ITESO 2001.

[25] Janoschka M. Die Flucht vor Gewalt? Stereotype und Motivation beim Andrang auf barrios privados in Buenos Aires. (Escape from violence? Stereotypes and motivation in the quest for barrios privados in Buenos Aires). Geogr Hel 2002; 57(4): 290-9.

[26] Bürkner HJ, Zehner C. Technological recesses y raíces locales de place-making: tres estudios de caso urbanos. (Technological recesses and local roots of place-making: three urban case studies). In: García OH, Bürkner HJ, Eds. Gobernanza y gestión del agua en el occidente de México: la metrópoli de Guadalajara. (Water Governance and Management in West Mexico: The Metropolis of Guadalajara). Guadalajara: ITESO 2012; pp. 285-318.

[27] Zehner C. Alternative Formen des lokalen Wassermanagements in der Metropolregion Guadalajara - Potenziale und Risiken nichtstaatlicher Versorgung. (Alternative types of local water management in the metropolitan region of Guadalajara: potentials and risks of non-state supply). In: Alfaro d'Alençon P, Imilan WA, Sánchez LM, Eds. Lateinamerikanische Städte im Wandel: Zwischen lokaler Stadtgesellschaft und globalem Einfluss. (Latin American cities in transition: between local urban society and global influence). Berlin: Lit 2011; vol. 16: pp. 39-50.

[28] Gopakumar G. Lived technical systems: Conceptualizing technologies and technology policies for the recesses of networked urban space in the Third World. In: Wilding P, Ed. Urban infrastructure in transition: What can we learn from history? International Summer Academy on Technology Studies. Deutschlandsberg 2004; pp. 71-85.

[29] Del Cueto C, Luzzi M. Betrachtungen über eine fragmentierte Gesellschaft. Veränderung der argentinischen Sozialstruktur (19832008). (Considerations about a fragmented society: Change in the social structure of Argentina (1983-2008)). In: Birle P, Bodemer K, Pagni A, Eds. Argentinien heute. (Argentina today). Frankfurt/M.: Vervuert 2010; pp. 33-54.

[30] Borsdorf A, Hidalgo R, Sánchez R. A new model of urban development in Latin America: The gated communities and fenced cities in the metropolitan areas of Santiago de Chile and Valparaíso. Cities 2007; 24(5): 365-78.

[31] Borsdorf A, Hidalgo R. New dimensions of social exclusion in Latin America. From gated communities to gated cities. The case of Santiago de Chile. Land Use Policy 2008; 25(2): 153-60.

[32] Ewaldt J. Individuelle coping strategies unterer Mittelschichten im urbanen Transformations prozess: Anpassungshandlungen der Bewohner von condominios in Santiago de Chile. (Individual coping strategies of lower middle classes in the process of urban transformation: Adaptation by residents of condominios in Santiago 
de Chile). Potsdam: Universitätsverlag Potsdam 2013 (Praxis Kultur- und Sozialgeographie; vol. 58).

[33] Argüelles K, García LE. Construcción de nivel socioeconómico predominante por AGEB mediante análisis multivariado. (Computation of the socio-economic level for AGEB using Multivariate Analysis). Blog AMAI 2013. Available from: http://blog.amai.org/ index.php/construccion-de-nivel-socioeconomico-predominante-po r-ageb-mediante-analisis-multivariado/

[34] Cruz Serrano N. Detecta Infonavit abandono de $34 \%$ de las viviendas. (Infonavit detects that $34 \%$ of houses are vacant). Mexico: El Universal 2013.

(C) Budke et al.; Licensee Bentham Open.

This is an open access article licensed under the terms of the Creative Commons Attribution Non-Commercial License (http://creativecommons.org/licenses/by-nc/3.0/) which permits unrestricted, non-commercial use, distribution and reproduction in any medium, provided the work is properly cited. 